\title{
Insights into immunopathology and triggering of apoptosis in chronic cerebral toxoplasmosis using murine models
}

\author{
El Saftawy, E.A. ${ }^{1,2}$, Shash, R.Y. ${ }^{3}$, Aboulhoda, B.E. ${ }^{5}$, Arsanyos, S.F. ${ }^{5}$ Albadawi, E.A. ${ }^{6}$, Abou-Fandoud, S.M. ${ }^{7}$, \\ Kamel, R.M. ${ }^{8}$, Amin, N.M. ${ }^{1,4^{*}}$
}

${ }^{1}$ Medical Parasitology Department, Faculty of Medicine, Cairo University, Cairo, Egypt

${ }^{2}$ Armed Forces College of Medicine, Cairo, Egypt

${ }^{3}$ Medical Microbiology and Immunology Department, Faculty of Medicine, Cairo University, Cairo, Egypt

${ }^{4}$ Master Degree of Clinical and Chemical Pathology, Faculty of Medicine, Cairo University, Cairo, Egypt

${ }^{5}$ Anatomy and Embryology Department, Faculty of Medicine, Cairo University, Egypt

${ }^{6}$ Anatomy Department, College of Medicine, Taibah University, KSA

7 Pathology Department, Faculty of Medicine, Cairo University

8 Psychiatry Department, Faculty of Medicine, Cairo University

*Corresponding author: nmabdelrazek@kasralainy.edu.eg

\section{ARTICLE HISTORY}

Received: 6 August 2020

Revised: 12 January 2021

Accepted: 19 January 2021

Published: 30 April 2021

\begin{abstract}
Background: toxoplasmosis is a cosmopolitan protozoan disease with a wide range of neuropathology. Recent studies identified its potential association with several mental disorders e.g. schizophrenia dependable on apoptosis in their pathogenesis. We investigated value of toxoplasmosis to induce apoptosis of the neuronal cells. Methods: per-orally infected C57BL/6 mice with $15-20$ cysts of the avirulent $T$. gondii Beverly strain at 9-11 weeks of age were examined 12 weeks later during parasite establishment. Distributions of the parasite's cysts and the histopathological lesions in the brains were analyzed using Image J software. Relative expression of TNF- $\alpha$ and iNOS of cell-mediated immunity (CMI), Bax (pro-apoptosis) and $\mathrm{Bcl}-2$ (anti-apoptosis) were all assessed using immunohistochemistry. Results: higher parasite burden was seen in the forebrain with $p$ value $\leq 0.05$. Dramatically increased TNF- $\alpha$, iNOS, and Bax expressions with Bax/Bcl-2 ratio 2.42:0.52 were reported ( $p$ value $\leq 0.05$ ). The significant correlation between $\mathrm{Bax}$ data and different $\mathrm{CMI}$ biomarkers including TNF- $\alpha$ and i-NOS was evaluated. Interestingly, no significant correlation was seen between TNF- $\alpha$, iNOS, Bax and Bcl-2 expressions and location of the parasite. However, $\mathrm{Bax} / \mathrm{BCl}-2$ ratio was statistically correlated with $\mathrm{CMI}$ biomarkers and whole sample mean parasite burden, $p$ value $\leq 0.05$. Conclusion: Chronic toxoplasmosis exhibits an immense pro-apoptotic signal on the cerebral tissues of experimental mice.
\end{abstract}

Keywords: Cerebral; toxoplasmosis; TNF- $\alpha$; Bcl-2; Bax

\section{INTRODUCTION}

Toxoplasma gondii ( $T$. gondii) is a apicomplexan protozoa that infects warm-blooded vertebrates; Aves and mammals, including human-beings (Dubey et al., 2008). Infections with the parasite despite often being asymptomatic, $T$. gondii can cause grave morbidity and death in humans and animals. $T$. gondii infection is so devastating thanks to the three main routes of transmission including placental transmission, ingestion of infected animal tissues containing bradyzoites, and ingestion of the parasite's oocysts due to environmental contamination (Carme et al., 2002; Jones et al., 2012).

The most infection site is within cerebral cells, wherein the low-virulent strains of the parasite are in the form of cysts containing hundreds of bradyzoites in a sluggish replicating state (Berenreiterová et al., 2011). Postnatally acquired toxoplasmosis despite being supposed to be latent in immunocompetent subjects (Mortensen et al., 2007; Bouscaren et al., 2018; Flegr \& Horacek, 2020) several studies related mental diseases to high anti-toxoplasma titers (Torrey et al., 2012; Flegr \& Escudero, 2016) making the real impact of the parasite on the surrounding cerebral cells a precisely questionable point. For example, Toxoplasmaseropositive schizophrenia patients expresses more eminent positive schizophrenia symptomology (Karabulut et al., 2015). Typically for this subset of patients there had been documented alterations in cerebral morphology such as reduction in the gray matter of the frontal and the temporal cortices, median cingulate, thalamus, and caudate (Daryani et al., 2010; Arias et al., 2011; Okusaga et al., 2011).

Immune scenario in $T$. gondii is carried out primarily by IL-12 from the stimulated dendritic cells which activates NK 
and $T$ cells to synthesize interferon-gamma (IFN- $\gamma$ ) to orchestrate the whole immune matter in concern with the cell-mediated immunity. This sequentially involves stimulation of inducible nitric oxide synthase (i-NOS) enzyme and the production of Tumor necrosing factor- $\alpha$ (TNF- $\alpha$ ) (Johnson et al., 1992, Lüder et al., 2003; Bando et al., 2018).

Up to date, way of control exerted by TNF- $\alpha$ and i NOS to hinder the persistence of the toxoplasma still a matter of study. In 2014, a review article published by Olmos and Lladó linked high expression of TNF- $\alpha$ to excito-toxicity and neuroinflammation. TNF- $\alpha$ has been reported to mediate the release of cytochrome $c$ from the mitochondria and induce oligomerization of Bak-Bax into a high molecular mass protein complex in mitochondrial membranes (Degenhardt et al., 2002). Also, NO and oxygen spp. had been linked to demyelination in a previous review article (Smith et al., 1999). Neuronal apoptosis had been deduced to associate TNF- $\alpha$ dependent i NOS release (Heneka et al., 1998; Combs et al., 2001).

Bcl-2 family had been documented to play a pivotal role in inducing or suppressing intrinsic apoptotic pathways caused by mitochondrial dysfunction (Chipuk et al., 2004). $\mathrm{Bax}$ and $\mathrm{Bcl}-2$ are two major members of $\mathrm{Bcl}-2$ family with a crucial role in the progression or inhibition of intrinsic apoptosis generated from mitochondrial dysfunction. Therefore, the refinement between pro- and anti-apoptotic factors in $\mathrm{Bcl}-2$ family can determine the survival fate of the cells.

Triggering of apoptosis by infections despite being distressing to the host, cell death appears to be an imperative way for the eradication of the intracellular pathogens (Williams, 1994). However, it is not surprising to discover that parasites, viruses, and bacteria have evolved tactics and several strategies to overwhelm this programmed cell death (Friedrich et al., 2017). During replication and establishment of $T$. gondii infection the parasite induce a media of anti-apoptotic scent in their host cells via targeting pro-apoptotic activity of Bax and Bak to suppress the intrinsic apoptogenic role of mitochondria such as selective degradation of $\mathrm{Bcl}-2$ members, redistribution of cytochrome C from mitochondria to the cytosol, and delaying of caspase activation. Moreover, extrinsic apoptosis induced by Fas-Fasligand pathways was also found not to be altered (Carmen et al., 2011; Wu et al., 2016; Chu et al., 2017). Yet, most studies concerted with the parasitized cells while little is known about the bystander host cells.

We aimed in the present study to validate toxoplasmosis as an apoptosis triggering model for mental health studies. Our experiment manipulated the parasite weight and its associated cell mediated immunity versus expression of pro and anti-apoptosis factors and defined $\mathrm{Bax} / \mathrm{Bcl}-2$ ratios in the bystander cerebral cell during established cerebral toxoplasmosis.

\section{MATERIALS AND METHODS}

\section{Animals and Experimental Design}

Ten unisex (male) 9-11 weeks old immune-competent mice of average weight $35-40 \mathrm{gm}$ of $\mathrm{C} 57 \mathrm{BL} / 6$ strain were utilized for the experiment as it entails especially i-NOS activity (one of the utilized biomarkers in the study) to control chronic $T$. gondii similarly to humans. It is worthy to mention that the research team avoided using some mice strains such as $\mathrm{BALB} / \mathrm{c}$ mice as it is resistant to T. gondii in a mechanism independent of the iNOS enzyme (Schlüter et al., 1999; Mahmoudvand et al., 2016). Age and sex matched mice were used as healthy controls in the current study.
The experimental supplements were acquired from the Laboratory Animal House interconnected to the Parasitology Department in Theodor Bilharz Research Institute, Egypt. Outbred mice were put into full terms of proper housing conditions according to the "Guidelines for the Care and Use of Laboratory Animals" and were accepted by the Institutional Animal Care and Use Committee, Cairo University, recorded by $\mathrm{CU} / \mathrm{III} / \mathrm{F} / 52 / 19$. Animal care involved balanced diet formula, all sanitary conditions, elimination of dead bodies, adjusted breeding temperature $\left(32^{\circ} \mathrm{C}\right)$, light pattern (12 h dark/12 h light), and suitable humidity. The serological check-up was periodically achieved by the research unit to assure that the murine models are pure of any other communal pathogens such as viral hepatitis (Szabo \& Finney, 2017). A well-trained laboratory technician terminated the experiment on the 12 weeks post-infection (104 days) by cervical dislocation of the sample study.

\section{Parasite Inoculation}

Cystogenic strain of $T$. gondii, Beverly strain (type-II) (ElZawawy et al., 2015), was obtained from the National Research Center, Giza, Egypt. Cysts for use in the experiment were obtained from murine model sacrificed by cervical dislocation 8 or above weeks after it had been infected; brains were smashed manually using the tissue grinder, Teflon pestle provided in a sterile Falcon tube. Brains homogenates were then suspended in $2 \mathrm{~mL}$ of Hanks' Balanced Salt Solution (HBSS). A $20 \mu \mathrm{L}$ wet mount sample was to be inspected via the light microscopy, in a magnification power of $40 x$ and the parasite's cysts were counted; in this accordance, one cyst in a $20 \mu \mathrm{L}$ was considered to be correlated with 100 cysts in the whole $2 \mathrm{~mL}$ sample suspension (the detective limit of the infective sample). In this study, the infection was carried out per-oral by administrating a suspension of $0.25 \mathrm{~mL}(0.9 \% \mathrm{NaCl})$ that contained 15-20 cysts of the low virulent Beverly strain. Brains of the infected mice in the two groups were then harvested 12 weeks later. Classical laboratory signs of acute toxoplasmosis in the form of arched posture, coarse rough fur, and lethargy were not documented post-infection as it's a chronic strain (Berenreiterová et al., 2011).

\section{Quantification of Histological Sections Containing the Parasite} Using hematoxylin and eosin stained cerebral tissue cut sections and Olympus microscopy (40X) images were taken for all brain areas gathered from the infected murine. Images were introduced into Image J software to be gridded as such to assign and compute the toxoplasms within certain squares with defined and automatically calculated pixel area. Wherever, the host cells' and parasites' nuclei can't be discerned counting was dismissed. The mean cysts number $(C / N)$, and the mean pixel areas $(A / N)$ were attained to calculate the average no. of parasite's cysts per pixel ${ }^{2}$ using this equation (Ferguson \& Murray, 1971; Moon et al., 2013; Russ \& Russ, 2017):

\section{$\frac{C / N}{A / N}$}

C: no. of Toxoplasma cysts; N: number of deployed squares; A: area/point.

\section{Immunohistochemistry}

Formalin-fixed and paraffin-embedded cerebral murine tissue preparations were adjusted for the process. The study followed the mouse on Mouse (MOM) protocol and the kit instructive brochure for the immune staining; in this regard, the tissue cut sections were incubated in Hydrogen Peroxide 
Block stock solution included in the Thermo Scientific Ultra Vision kits for 10-15 min. Hence, the nonspecific background staining was blocked.

We escorted down the following primary monoclonal antibodies of rodent origin to detect the following individual biomarkers: (1) Anti-Murine Tumor Necrosis Factor-alpha (TNF- $\alpha$ cytokine) antibody: monoclonal un-conjugated murine IgM, kappa antibody clone DBM15.28 (\#Mob502) of high affinity to $17-26 \mathrm{kDa}$ protein that react with cytoplasmic and secreted extracellular TNF- $\alpha$ (2) Anti-Inducible nitric oxide synthase (iNOS) enzyme antibody: polyclonal IgG antibody (\#MBS9406022) of rabbit origin specific to the peptide sequence nearby the phosphorylation site of tyrosine 151 in human iNOS enzyme; (3) Anti-Bax antibody: murine polyclonal IgG antibody (\#ab216494) specific to mitochondrial and cytoplasmic BAX aa sequence of murine origin conjugated to keyhole limpet hemocyanin; (4) Anti-Bcl-2 antibody: polyclonal IgG to Bcl-2 (\#ab59348) of rabbit origin specific to the total endogenous BCL-2 levels.

The primary antibody was diluted in 1:200 applied and incubated with the tissues. In whatever biomarker and relying on the percepts of several previous experiments, the dilution of the primary antibody was adjusted in $\mathrm{pH} 7.4$ $\left(10 \mathrm{mmol} / \mathrm{L} \mathrm{CaCl}_{2}, 1 \% \mathrm{BSA}\right.$ and $\left.0.1 \% \mathrm{NaN}_{3}\right)$ and TBS of 20 $\mathrm{mmol} / \mathrm{L}$. Each of the tested tissue cut sections was tested for a single supreme biomarker. Tissue cut sections were then allowed to be incubated with the applied primary antibodies overnight in a temperature adjusted at $37^{\circ} \mathrm{C}$.

Thereafter biotinylated goat anti-polyvalent secondary antibody was applied on the tissue cut sections and allowed to be incubated for $10 \mathrm{~min}$. adjusted at $25^{\circ} \mathrm{C}$ to bind with the primary antibody. The final staining was performed in a solution of diaminobenzidine tetrahydrochloride (DAB) (34 $\mathrm{mg}$ imidazole, $49 \mathrm{~mL}$ TBS-buffer, $1 \mathrm{~mL} 30 \% \mathrm{DAB}, 17 \mu \mathrm{L}$, and $30 \%$ hydrogen peroxide) for 10-20 min. EconoTek HRP (DAB) Antipolyvalent kits (\# AEX080) were purchased from ScyTek Laboratories, Logan, Utah, USA. Each step in the whole immunohistochemistry staining process was followed by PBS wash four to six times at $25^{\circ} \mathrm{C}$ for 5-10 minutes each. The tissue nuclei were stained with Mayer's hematoxylin as a counterstain for $1 \mathrm{~min}$. The extra stain was washed afterward with tap water (El-Aal et al., 2015). Control slides were performed where the step of primary antibody was dismissed.

\section{Real-Time Quantitative Morphocytometry}

Leica Qwin Analyzer, 500 images (LEICA Imaging System Ltd., Cambridge, England) which is a digital real-time quantitative photocytometry was used in the present study for the patho- logical analysis and the quantitative real-time morphometric measurement. Immune staining was automatically calculated in ten fields in each tissue cut section at low (10x) and high magnification powers (100x). All recorded values were saved for fairly statistical analysis (El-Aal et al., 2015).

\section{Statistical Methods}

Data were introduced via Microsoft Excel (2013) and analyzed statistically using version 24 of the Statistical Package for the Social Sciences (SPSS). Simple descriptive statistics in the form of the median interquartile range were used to summarize the skewed quantitative data; in addition to the frequencies for the qualitative data (percentiles). MannWhitney and Spearman's rho correlation tests were used to compare the quantitative variables of abnormal distribution. P-values $\leq 0.05$ were considered significant. R-value was considered negative or positive according to its sign where the results of $<0.5$ assures the weak correlation, 0.5-0.7 are of moderate correlation, and $>0.7$ refers to the strong correlation (Chan, 2003a, 2003b, 2003c).

\section{RESULTS}

T. gondii established several niche-like cystic lesions in the cerebral tissues (Figure 1). The lesions are remarkable for the parasite's chronicity and contain hundreds of bradyzoites encased by cyst wall. No significant histological changes can be noted but for some inflammatory cells. Since the parasite was not isolated out of tissues micrometry was not performed to evade false measurement. Unifying the parasite strain and infection dose contributed to the insignificant variations in the total parasite counts among the experimental mice $p$-value $>0.05$.

As much as $80 \%$ of the examined brain regions were confined with tissue cysts; however, toxoplasma's burden steadily increased in the forebrain. Ratios of mean counts of the parasite's cysts to the mean pixel area in the forebrain tissue cut-sections were of insignificant differences ( $p$-value $>0.05$ ) while being of significantly different $p$-values $\leq 0.05$ when compared with other cerebral areas e.g. brain-stem in (Figure 2). The study displayed the histological and immunestained comparisons between two fixed cerebral areas; amygdala in the forebrain and pons in the brain-stem.

\section{- Bioassay of Cell-Mediated Immune Response (CMI) (i-NOS and TNF- $\alpha$ )}

Compared with healthy mice, the number of iNOS and TNF- $\alpha$ positive cells were much higher in the examined brains of
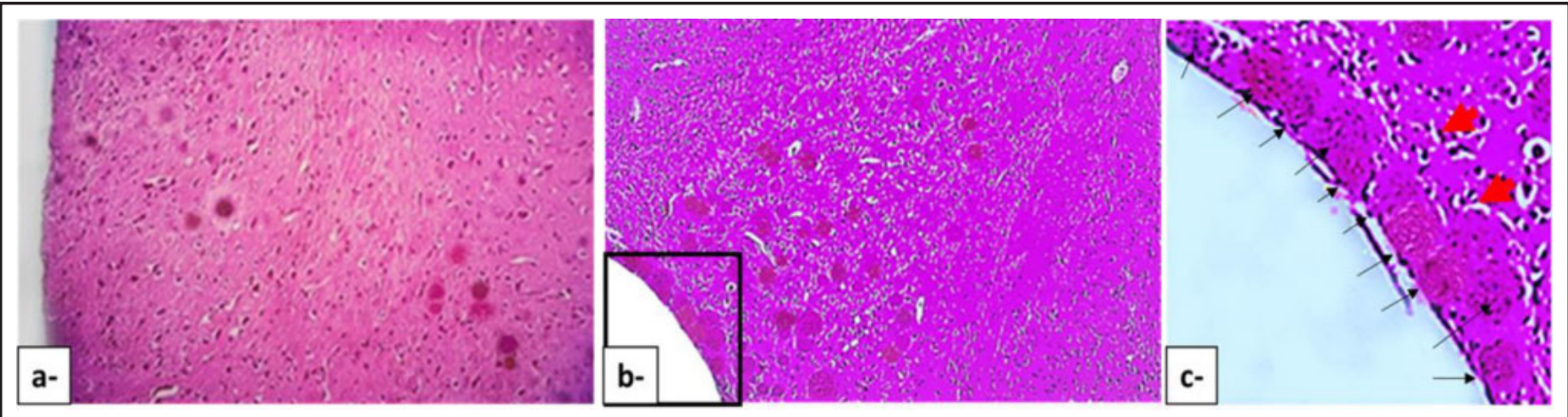

Figure 1. Hematoxylin \& eosin stain shows intra-cerebral Toxoplasma cysts in Beverly strain (type-II)-infected C57BL/6 mice (40X), $12^{\text {th }}$ weeks post-infection. a: Pontine part of the hind brain with scattered cysts of variable sizes (b). Amygdala region of the forebrain stacked with cysts containing hundreds of bradyzoites. Note the dot-like nuclei at black arrow heads embraced in the parasite's cysts and the infiltrating inflammatory cells (red head arrows) in (c); a cropped magnified figure from b. 


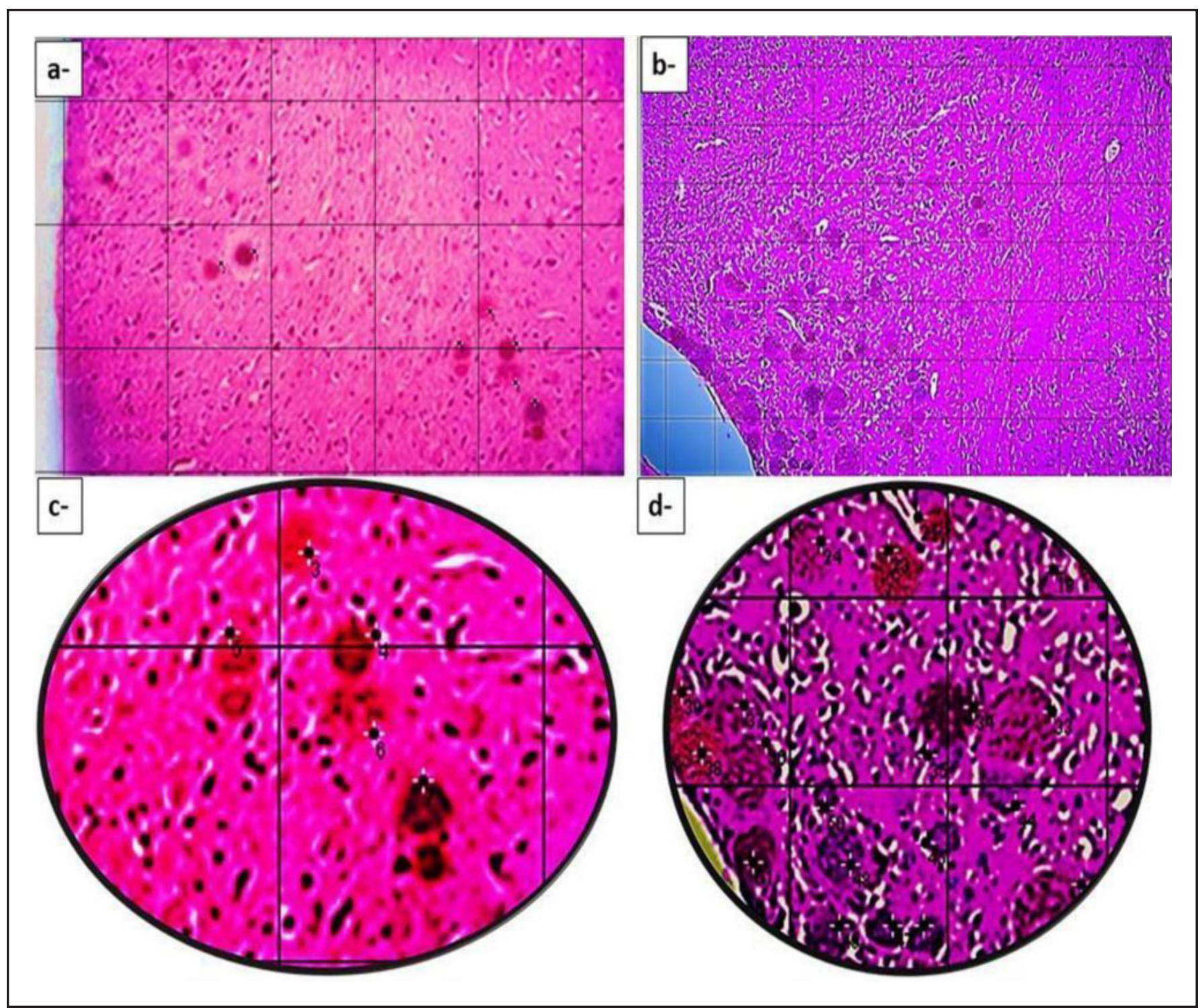

Figure 2. Quantification of intra-cerebral Toxoplasma cysts in tissue cut sections (H\&E stain, 40X). Image gridding (black in colour) was performed by ImageJ software and the parasites were manually selected (numerated asterisk). (a) Pons region with discrete cysts (7cysts) and (b) amygdala region with gatherings of cysts (48cysts). Note (c,d) are cropped magnified images from $a$ and $b$ successively.

Beverly strain (type-II)-infected C57BL/6 mice (Figure 3) $p$-value $\leq 0.05$. TNF- $\alpha$ immune-reactive cells had a similar distribution iNOS positive cells, with a higher number located perivascular. Immune-staining for i-NOS frequently revealed numerous positive immune cells in close vicinity to the parasite's cysts. There were no significant differences between pons and amygdala regions.

i-NOS was statistically of high transmittance expression in established cerebral toxoplasmosis (mean value was $2.66 \pm 0.72$ for O.D. and $55 \pm 7.9$ for area $\%$ ) ( $p$-value $\leq 0.05$ ) compared with healthy control (Figure $4-a)$. TNF- $\alpha$ was of mean O.D $2.1 \pm 0.5$ and area\% $46 \pm 9.6$ with a statistically significant difference ( $p$-value $\leq 0.05)$ when compared with the healthy control (Figure $4 b$ ).

\section{- Immune- expression assay of apoptotic biomarker}

There was no significant association of $\mathrm{Bcl}-2$ positive cells with established cerebral toxoplasma cysts. Some $\mathrm{Bcl}-2$ positive cells were present perivascular. Both pons and amygdala regions had significantly increased Bax and Bax/
Bcl-2 ratio compared to healthy controls $p$ value 0.003 and $p$ value 0.001 respectively using 2 -way ANOVA. There was no significant correlation between Bax expression and parasite location $(p>0.05)$.

Mean values of Bax were $2.42 \pm 0.5$ for O.D. and $41 \pm 8.2$ for area $\%$ in the infected animals while in healthy control mean values were $0.78 \pm 0.2$ for O.D. and $20 \pm 6.5$ for area\% ( $p$ value $0.001)$. Bcl-2 mean values were $0.52 \pm 0.3$ for O.D. and $15 \pm 7.9$ for area\% post-infection whereas in healthy controls O.D. was $2.57 \pm 0.29$ and area\% was $58.13 \pm 11.6$ ( $p$ value 0.001 ). Relative $\mathrm{Bax} / \mathrm{Bcl}-2$ ratio in the infected animals was 2.42:0.52 while in healthy control $\mathrm{Bax} / \mathrm{Bcl}-2$ ratio was $0.78: 2.57$ with $p$ value 0.001 .

\section{- Association Between CMI and Apoptosis Biomarkers}

Pearson Correlation showed a positive relation-ship between $\mathrm{CMI}$ biomarkers and Bax, the pro-apoptotic biomarker. The correlation factor between densities of TNF- $\alpha$ and i-NOS versus $\mathrm{Bax} / \mathrm{Bcl}-2$ ratio was of rho value 0.76 and 0.686 respectively, $p$ value $\leq 0.05$. 

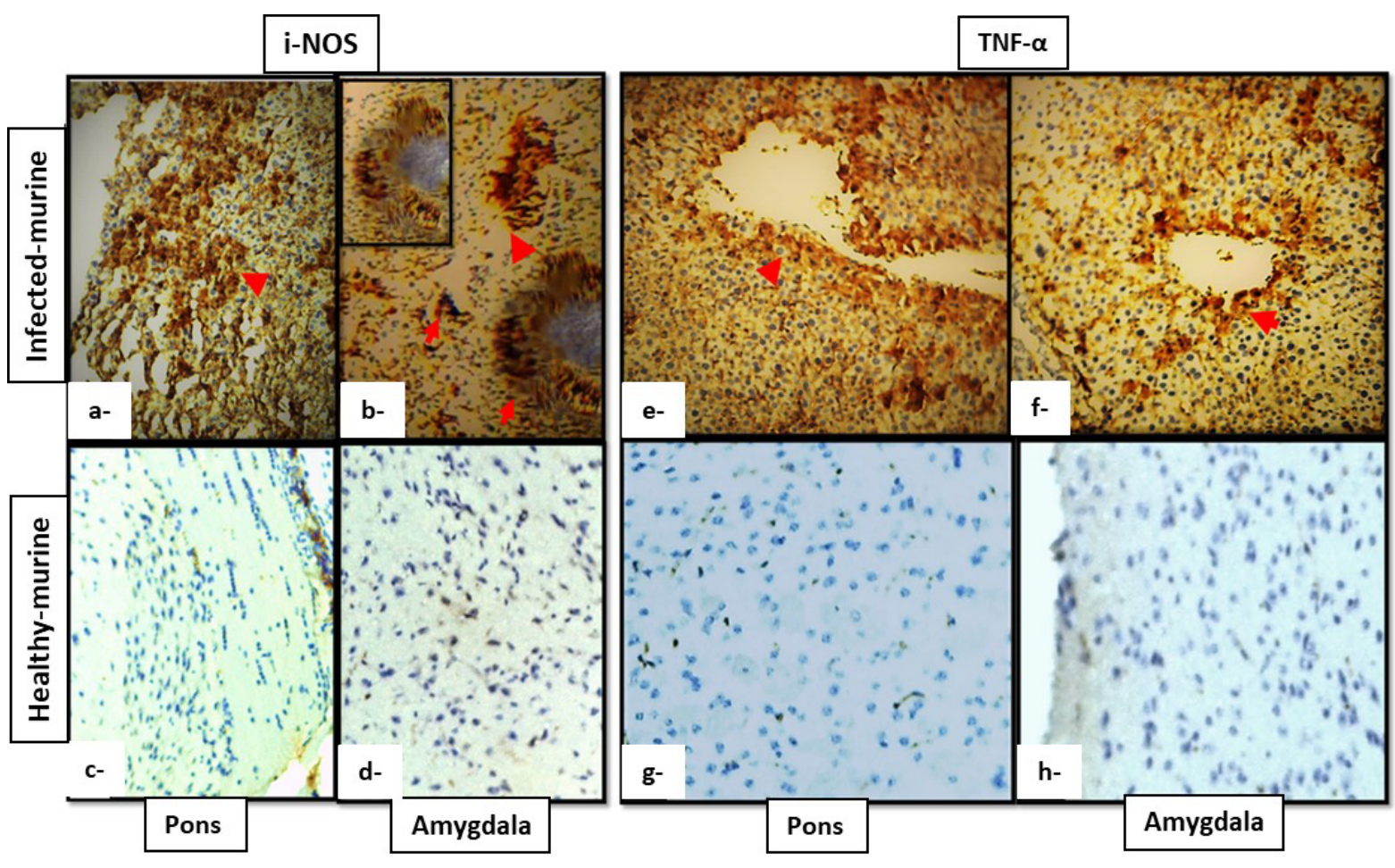

Figure 3. Immunohistochemical assessment of both Beverly strain (type-II)-infected C57BL/6 mice $12^{\text {th }}$ wks. post-infection and healthy mice with anti-iNOS $(a, b, c, d)$ and anti-TNF- $\alpha$ antibodies $(e, f, g, h)$. iNOS expression in infected mice: (a) cerebral cells with cytoplasmic immune-reactivity in pons region. Red arrows point to area of intense perivascular immune staining. (b) Several iNOS immune reactive cells in amygdala region and the upper-left cropped image shows iNOS immune reactive cells surrounding an established cyst. iNOS expression in healthy controls: (c,d) shows cerebral cells along the healthy pons and amygdala regions without immune-reactivity. TNF- $\alpha$ expression in infected-mice: $(e, f)$ cytoplasmic expression of TNF- $\alpha$ cytokine, red arrow points at peri-vascular immune-reactive cerebral cells in pons and amygdala regions; meanwhile (g,h) negative TNF$\alpha$ expression in healthy cerebral controls. Magnification power (100X).

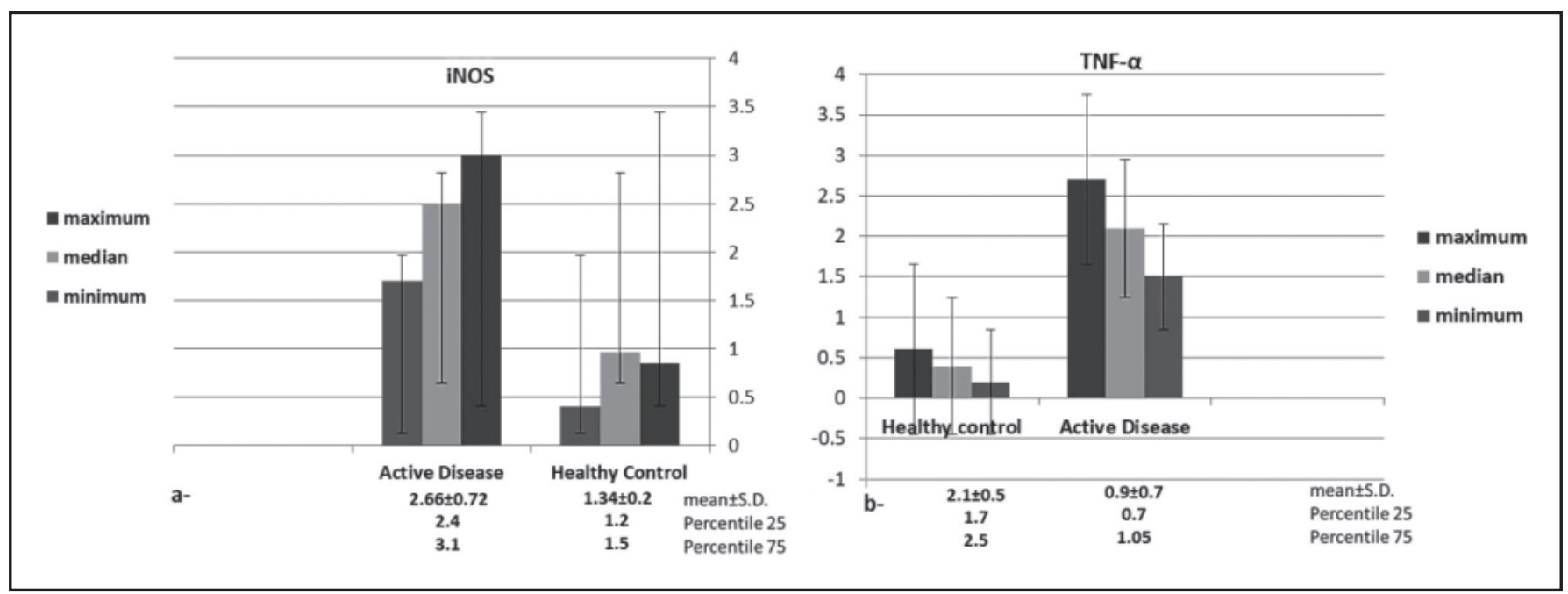

Figure 4. Bar graph represents the median, the minimum and the maximum values of the O.D. in the biomarkers of the CMI in the two independent experiments at the $12^{\text {th }}$ wks. post- $T$. gondii infection. Below each graph mean $\pm S$.D, percentile 25 , and percentile 75 were demonstrated, $p$-value $\leq 0.05$.

\footnotetext{
- Pearson correlation analysis of Averages of Parasite burden and Alterations in the Biomarkers' Expressions

Mean cyst number of the parasite in the whole sample was positively correlated to the cell mediated immunity (TNF- $\alpha$
}

and iNOS) of rho value 0.858 and 0.9 respectively, $p$ value $\leq 0.005$ and yielded positive correlation with $B a x$ and $\mathrm{Bax} / \mathrm{Bcl}-2$ ratio, rho value $0.68, p$ value 0.04 and rho value $0.72, p$ value 0.002 , respectively. 


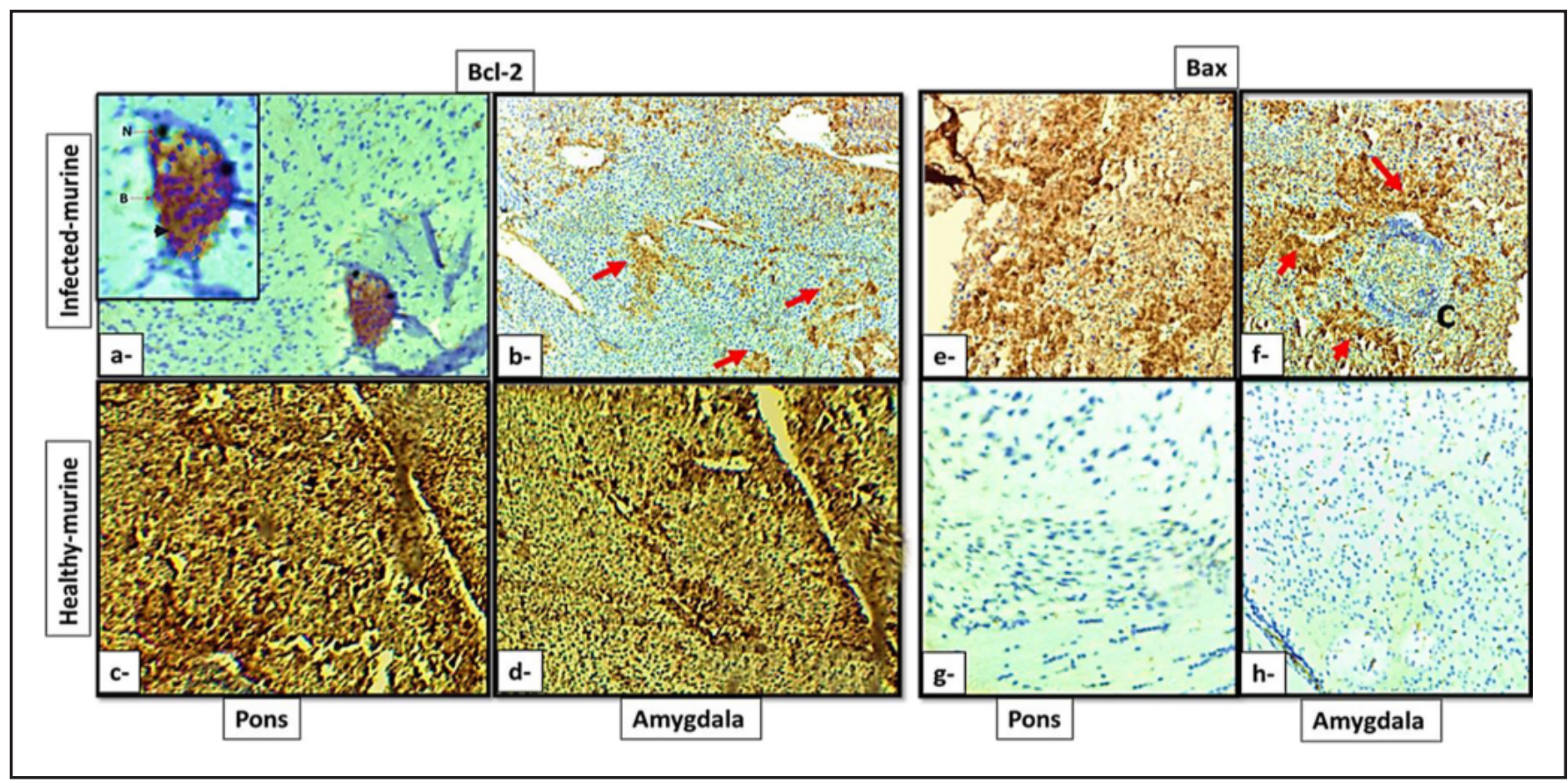

Figure 5. Immunohistochemical localization of both Beverly strain (type-II)-infected C57BL/6 mice and healthy mice with anti-Bcl-2 (a,b,c,d) and anti-Bax antibodies (e,f,g,h). Bcl-2 expression in infected mice: (a) a cropped magnified image in the upper-left showing Toxoplasma cyst, black head arrow points to Bcl-2 cytoplasmic expression, (N) refers to host eccentric nucleus, (B) is the basophilic dot-like nuclei of the parasites; meanwhile neighboring cerebral cells are without immunereactivity. (b) Red arrows points at occasional perivascular $\mathrm{Bcl}-2$ immune reactive cells in amygdala region. Bcl-2 expression in healthy controls: (c,d) Bcl-2 was confined chiefly in the cytoplasm of the positive cerebral cells along the healthy pons and amygdala regions. Bax expression in infected-mice: $(e, f)$ nuclear expression of Bax, red arrow points at positive perivascular cerebral cells and in ( $f$ ) around the parasite's cyst $(C)$; meanwhile $(g, h)$ negative Bax expression in healthy cerebral controls. Magnification power (100X).

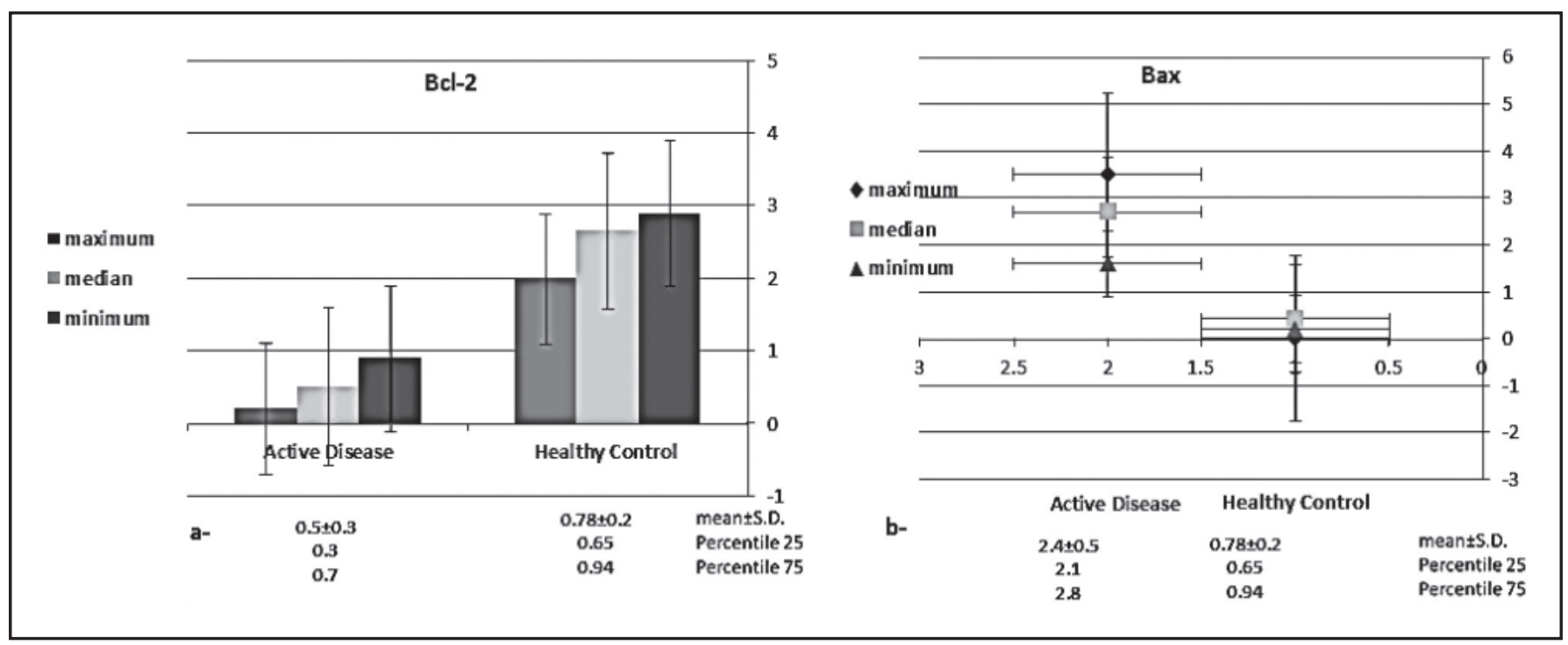

Figure 6. Scattered points and bar graph are representative for O.D. of the apoptotic biomarkers in the two-independent experiments, $12^{\text {th }}$ wks. post-infection in the form of median, minimum, and maximum values. Below each paragraph mean \pm S.D, percentile 25 , and percentile 75 are also demonstrated, $p$-value 0.001 .

\section{DISCUSSION}

Factors beyond $T$. gondii cerebral dissemination despite being vague parasite cysts were of un even distributive pattern in all brain regions but similar to prior studies higher cyst densities were detected in forebrain (amygdala) (Berenreiterová et al., 2011).
Remarkable stimulation of cell-mediated immunity represented by high expression iNOS and TNF- $\alpha$ was in association to the parasite establishment. Lüder et al. (2003) reported the mandatory role of nitric oxide (NO) production during toxoplasmosis noting that its partial suppression by the parasite may modify the parasite-host balance. However, Schlüter et al. (1999) related real impact of i-NOS during the 
parasite infection to the mouse strain as suppression of iNOS exacerbates chronic cerebral toxoplasmosis in C57BL/6 mice while being irrelevant in BALB/c murine models. It is noteworthy to mention that using i-NOS ${ }^{-/}$mice, the experimental animals survived the acute infection of the parasitic disease. iNOS was also reported to be essential to control the persistent intracellular infection, which is a tissue-specific effect rather than systemic (Scharton-Kersten et al., 1997).

Another point, Dincel and Atmaca in (2015) indicated the role of increased iNOS and NO levels to contribute to neuropathology related to toxoplasmosis encephalitis. Also, a former study published by Mahmoudvand et al. (2015) (46) identified the possible relation-ship between iNOS in $T$. gondii infection and increased risk of anxiety and mental disorders together with other cytokines such as IL-1 $\beta$, TNF- $\alpha$, IL-6 experimentally in BALB/c mice. An experimental study using rats reported that aminoguanidine, an i-NOS inhibitor, can counteract schizophrenia-like behavioral changes induced by ketamine and apomorphine (Lafioniatis et al., 2016).

Interestingly, one human study deduced that i-NOS promotes the growth of Toxoplasma; as i-NOS appeared to reduce levels of indole 2,3- dioxygenase 1 (IDO1) protein which is critical to induce IFN-ö in toxoplasmosis (Bando et al., 2018). In 2012, Tobin and Knoll recognized a patatin-like protein which protects $T$. gondii from degradation by NO using an un-known mechanism.

Schlüter et al. (2003) recorded that $\mathrm{TNF}^{-/}$mice failed to control intracerebral toxoplamosis and yielded to acute necrotizing encephalitis. A challenging study revealed that murine models lethally infected with C56 strain of $T$. gondii and treated with purified recombinant TNF $(1 \mathrm{mg} /$ day for 8 days) survived the infection (Chang et al., 1990). In vitro studies revealed that exogenous TNF- $\alpha$ could stimulate egress of $T$. gondii from fibroblast cells of human foreskin at a dose of $10 \mathrm{ng} / \mathrm{mL}$ in a time-dependent manner (Yao et al., 2017). TNF- $\alpha$ in former study was shown to regulate production of IFNö by NK cells (Hunter et al., 1994).

However, Halonen et al. (1998) demonstrated that collaboration of TNF- $\alpha$ with other cytokines involving IL-1 and IL- 6 is required for proper inhibition of the parasite growth. Also, in 2002 an in vitro study on human cells documented the capability of $T$. gondii parasite to regulate the expression of TNF- $\alpha$ receptors (Derouich-Guergour et al., 2002). In a human study, patients with symptomatic cerebral toxoplasmosis were shown to exhibit higher sera levels of TNF- $\alpha$ (Meira et al., 2014).

Similar to our results, Dincel and Atmaca (2016) suggested Toxoplasma-mediated apoptosis as an essential and different neuro-degenerative and neuro-pathological type involved in toxoplasmic encephalitis. Interestingly, Kim et al. (2019) demonstrated that a Toxoplasma-specific protein called GRA-16 can induce p53-dependent apoptosis in a referral to its probable anti-cancer effect. Another in vitro study reported induction of apoptosis in human leukaemia (K562)-cell after being treated with Toxoplasma tachyzoites (Zhang et al., 2007). In contrast to our results, Takahashi et al. (2001) (60) suggested that in congenital-murine toxoplasmosis there is no obvious relation-ship between cortical dysplasia and Bax-induced apoptosis. Raisova et al. (2001) assumed higher $\mathrm{Bax} / \mathrm{Bcl}-2$ ratio to the susceptibility of cells to apoptosis.
Cell mediated immunity positively correlated with Bax/ Bcl-2 ratio. Similarly, Nishikawa et al. (2007) reported apoptosis in non-infected bystander macrophages in a process related to NO released by infected-host cells lines. However, Khan et al. (1996) reported formerly induction of apoptosis in $\mathrm{CD}^{+} \mathrm{T}$ cells during Toxoplasma infection. Also, Liesenfeld et al. (1997) conveyed that per-orally murine infection with $T$. gondii induce apoptosis of $\mathrm{CD}^{+}$and $\mathrm{CD}^{+}$ in Peyer's patches associating INF-ö up regulation and increased Fas expression.

CMI biomarkers were heavily sensitized to the parasite burden in the whole sample. Strikingly, parasite burden despite being of non-homogenous pattern in all brain areas it seemed to render cerebral cells susceptible to apoptotic signals being relatable to $\mathrm{Bax} / \mathrm{Bcl}-2$ ratio (Raisova et al., 2001). We are then asking if boosting such pro-apoptotic signals had a substantial advantage on Toxoplasma -infected host cell survival. It has been previously reported that Toxoplasma-infected cerebral cells can resist apoptosis. This stimulus that is not physiologically relevant in the resting brain tissues. Although, it is interesting to illustrate the signaling in the infected cerebral tissues as strictly proapoptotic or pro-survival, the present data here propose a more multifaceted relationship between the burden of Toxoplasma parasite and its impact on the entire microenvironment of infected brain tissues than previously esteemed.

\section{CONCLUSION}

This is a comprehensive analysis of the apoptotic signal induced by chronic cerebral toxoplasmosis infection of murine brain model. Our study indicated higher parasite weight in the forebrain (presented by amygdala) compared to other brain regions (presented by pontine region). Activation of cell-mediated immunity biomarkers (i-NOS and TNF- $\alpha$ ) was observed in all infected brains. Expressions of i-NOS and TNF- $\alpha$ were positively correlated to the density of apoptotic factor and $\mathrm{Bax} / \mathrm{Bcl}-2$. Also, the average quantity of the parasites in the whole sample study positively correlated with the expression of the cell-mediated biomarkers (i-NOS and TNF- $\alpha$ ), Bax protein, and $\mathrm{Bax} / \mathrm{Bcl}-2$ ratio. The current model presented the toxoplasms latent infections as an apoptotic triggering factor in cerebral cells. In this accordance we are presenting our results as an experimental diagnostic tool for further studies on the role of toxoplasmosis in mental and physical health disorders and we recommend further studies correlating $\mathrm{Bax} / \mathrm{Bcl}-2$ ratio to the behavioral changes in established toxoplasmosis infection. Another point, speedily replicating parasites like $T$. gondii have been found to be competitive for combating, due to continual evolution and frequent development of drug resistance. Yet, little attention has been driven to improve drugs for selective provoking of apoptosis in parasite-infected cells while shielding the surrounding cellular microenvironment.

\section{ACKNOWLEDGEMENTS}

The authors thank DR Hany Ahmed Fouad Elghobary assistant professor of Chemical and Clinical Pathology, Cairo University for English revesion and editing.

\section{Disclosures}

The authors have no financial conflicts of interest. 


\section{REFERENCES}

Abd El-Aal, A.A., Emran, A.M., Al-Antably, A.S., El Saftawy, E.A., Bayoumy, I.R., Hassan, N.S. \& Badawi, M. (2015). Immunohistochemical pattern of $\mathrm{T}$ lymphocytes population within bilharzial-associated bladder neo-plasm microenvironment. International Journal of Immuno-pathology and Pharmacology 28: 209-217. https://doi.org/10.1177/ 0394632015584733

Arias, I., Sorlozano, A., Villegas, E., Luna, J.D., McKenney, K., Cervilla, J., Gutierrez, B. \& Gutierrez, J. (2011). Infectious agents associated with schziophrenia: a meta-analysis. Schizophrnia Research 136: 128-136. https://doi.org/10.1016/ j.schres.2011.10.026

Bando, H., Lee, Y., Sakaguchi, N., Pradipta, A., Ma, J.S., Tanaka, S., Cai, Y., Liu, J., Shen, J. \& Nishikawa, Y. (2018). Inducible nitric oxide synthase is a key host factor for toxoplasma GRA15-dependent disruption of the gamma interferoninduced antiparasitic human response. Host Microbe Biology 9: e01738-18. https://doi.org/10.1128/mBio.0173818

Berenreiterová, M., Flegr, J., Kubìna, A.A. \& Nìmec, P. (2011). The distribution of Toxoplasma gondii cysts in the brain of a mouse with latent toxoplasmosis: implications for the behavioral manipulation hypothesis. PLOS ONE 6: e28925. https://doi.org/10.1371/journal.pone.0028925

Bouscaren, N., Pilleron, S., Mbelesso, P., Ndamba-Bandzouzi, B., Dartigues, J.F., Clément, J.P., Preux, P.M., Dardé, M.L., Guerchet, M. \& EPIDEMCA Group (2018). Prevalence of toxoplasmosis and its association with dementia in older adults in Central Africa: a result from the EPIDEMCA programme. Tropical Medicine \& International Health 23: 13041313. https://doi.org/10.1111/tmi.13151

Carme, B., Bissuel, F., Ajzenberg, D., Bouyne, R., Aznar, C., Demar, M., Bichat, S., Louvel, D., Bourbigot, A.M. \& Peneau, C. (2002). Severe acquired toxoplasmosis in immunocompetent adult patients in French Guiana. Journal of Clinical Microbiology 40: 4037-4044. https://doi.org/10.1128/ JCM.40.11.4037-4044.2002

Carmen, J.C. \& Sinai, A.P. (2011). The differential effect of Toxoplasma gondii infection on the stability of BCL2-family members involves multiple activities. Frontiers in Microbiology 2: 1. https://doi.org/10.3389/fmicb.2011.00001

Chan, Y.H. (2003a). Biostatistics 102: Quantitative Data Parametric \& Nonparametric Tests. Singapore Medical Journal 44: 391-396.

Chan, Y.H. (2003b). Biostatistics 103: Qualitative Data - Tests of Independence. Singapore Medical Journal 44: 498-503.

Chan, Y.H. (2003c). Biostatistics 104: Correlational Analysis. Singapore Medical Journal 44: 614-619.

Chang, H.R, Grau, G.E. \& Pechere, J.C. (1990). Role of TNF and IL-1 in infections with Toxoplasma gondii. Immunology 69: 33.

Chipuk, J.E., Kuwana, T., Bouchier-Hayes, L., Droin, N.M., Newmeyer, D.D., Schuler, M. \& Green, D.R. (2004). Direct activation of Bax by p53 mediates mitochondrial membrane permeabilization and apoptosis. Science 303: 1010-1014. https://doi.org/10.1126/science.1092734

Chu, J.Q., Jing, K.P., Gao, X., Li, P., Huang, R., Niu, Y.R., Yan, S.Q., Kong, J.C., Yu, C.Y. \& Shi, G. (2017). Toxoplasma gondii induces autophagy and apoptosis in human umbilical cord mesenchymal stem cells via downregulation of Mcl-1. Cell Cycle 16: 477-486. https://doi.org/10.1080/ 15384101.2017.1281484
Combs, C.K., Karlo, J.C., Kao, S.C. \& Landreth, G.E. (2001). $\beta$ Amyloid stimulation of microglia and monocytes results in TNF $\alpha$-dependent expression of inducible nitric oxide synthase and neuronal apoptosis. Journal of Neuroscience 21:1179-1188. https://doi.org/10.1523/JNEUROSCI.21-0401179.2001

Daryani, A., Sharif, M., Hosseini, S.H., Karimi, S.A. \& Gholami, S. (2010). Serological survey of Toxoplasma gondii in schizophrenia patients referred to Psychiatric Hospital, Sari City, Iran. Tropical Biomedicine 27: 476-482.

Degenhardt, K., Sundararajan, R., Lindsten, T., Thompson, C. \& White, E. (2002). Bax and Bak Independently Promote Cytochrome cRelease from Mitochondria. Journal of Biological Chemistry 277: 14127-14134. https://doi.org/ 10.1074/jbc.M109939200

Derouich Guergour, D., Aldebert, D., Vigan, I., Jouvin Marche, E., Marche, P.N., Aubert, D., Ambroise Thomas, P. \& Pelloux, H. (2002). Toxoplasma gondii infection can regulate the expression of tumour necorsis factor- $\alpha$ receptors on human cell in vitro. Parasite Immunology 24: 271-279. https://doi.org/10.1046/j.1365-3024.2002.00462.x

Dincel, G.C. \& Atmaca, H.T. (2015). Nitric oxide production increases during Toxoplasma gondii encephalitis in mice. Experimental Parasitology 156: 104-112. https://doi.org/ 10.1016/j.exppara.2015.06.009

Dincel, G.C. \& Atmaca, H.T. (2016). Increased expressions of ADAMTS 13 and apoptosis contribute to neuropathology during Toxoplasma gondii encephalitis in mice. Neuropathology 36: 211-226. https://doi.org/10.1111/neup.12263

Dubey, J.P. \& Jones, J.L. (2008). Toxoplasma gondii infection in humans and animals in the United States. International Journal for Parasitology 38: 1257-1278. https://doi.org/ 10.1016/j.ijpara.2008.03.007

El-Zawawy, L.A., El-Said, D., Mossallam, S.F., Ramadan, H.S. \& Younis, S.S. (2015). Preventive prospective of triclosan and triclosan-liposomal nanoparticles against experimental infection with a cystogenic ME49 strain of Toxoplasma gondii. Acta Tropica 141(PtA): 103-111. https://doi.org/10. 1016/j.actatropica.2014.09.020

Ferguson, A. \& Murray, D. (1971). Quantitation of intraepithelial lymphocytes in human jejunum. Gut 12: 988994. https://doi.org/10.1136/gut.12.12.988

Flegr, J. \& Escudero, D.Q. (2016). Impaired health status and increased incidence of diseases in Toxoplasmaseropositive subjects - an explorative cross-sectional study. Parasitology 143: 1974-1989. https://doi.org/10.1017/ S0031182016001785

Flegr, J. \& Horacek, J. (2020). Negative effects of latent toxoplasmosis on mental health. Frontiers in Psychiatry 10: 1012. https://doi.org/10.3389/fpsyt.2019.01012

Halonen, S.K., Chiu, F.C. \& Weiss, L.M. (1998). Effect of cytokines on growth of Toxoplasma gondii in murine astrocytes. Infection and Immunity 66: 4989-4993. https://doi.org/ 10.1128/IAI.66.10.4989-4993.1998

Heneka, M.T., Löschmann, P.A., Gleichmann, M., Weller, M., Schulz, J.B., Wüllner, U. \& Klockgether, T. (1998). Induction of nitric oxide synthase and nitric oxide mediated apoptosis in neuronal PC12 cells after stimulation with tumor necrosis factor- $\alpha$ /lipopolysaccharide. Journal of Neurochemistry 71: 88-94. https://doi.org/10.1046/j.14714159.1998.71010088.x

Hill, D.E., Chirukandoth, S. \& Dubey, J.P. (2005). Biology and epidemiology of Toxoplasma gondii in man and animals. Animal Health Research Reviews 6: 41-61. https://doi.org/ 10.1079/ahr2005100 
Hunter, C.A., Subauste, C.S., Van Cleave, V.H. \& Remington, J.S. (1994). Production of gamma interferon by natural killer cells from Toxoplasma gondii-infected SCID mice: regulation by interleukin-10, interleukin-12, and tumor necrosis factor alpha. Infection and Immunity 62: 2818-2824. https:// doi.org/10.1128/IAI.62.7.2818-2824.1994

Johnson, L.L. (1992). A protective role for endogenous tumor necrosis factor in Toxoplasma gondii infection. Infection and Immunity 60: 1979-1983. https://doi.org/10.1128/iai.60.5. 1979-1983.1992

Jones, K.H., Wilson, F.D., Fitzgerald, S.D. \& Kiupel, M. (2012). A natural outbreak of clinical toxoplasmosis in a backyard flock of guinea fowl in Mississippi. Avian Diseases 56: 750753.

Karabulut, N., Bilgiç, S., Gürok, M.G. \& Karaboğa, F. (2015). Is there any role of latent toxoplasmosis in schizophrenia disease? Journal of Chinese Medical Association 78: 533-537. https://doi.org/10.1016/j.jcma.2015.06.007

Khan, I.A., Matsuura, T. \& Kasper, L.H. (1996). Activationmediated CD4+ T cell unresponsiveness during acute Toxoplasma gondii infection in mice. International Immunology 8: 887-896. https://doi.org/10.1093/intimm/8.6.887

Kim, S.G., Seo, S.H., Shin, J.H., Yang, J.P., Lee, S.H. \& Shin, E.H. (2019). Increase in the nuclear localization of PTEN by the Toxoplasma GRA16 protein and subsequent induction of p53 dependent apoptosis and anticancer effect. Journal of Cellular and Molecular Medicine 23: 3234-3245. https:// doi.org/10.1111/jcmm.14207

Lafioniatis, A., Orfanidou, M.A., Papadopoulou, E.S. \& Pitsikas, N. (2016). Effects of the inducible nitric oxide synthase inhibitor aminoguanidine in two different rat models of schizophrenia. Behavior Brain Research 309: 14-21. https:// doi.org/10.1016/j.bbr.2016.04.043

Liesenfeld, O., Kosek, J.C. \& Suzuki, Y. (1997). Gamma interferon induces Fas-dependent apoptosis of Peyer's patch T cells in mice following peroral infection with Toxoplasma gondii. Infection and Immunity 65: 4682-4689.

Lüder, C.G., Algner, M., Lang, C., Bleicher, N. \& Groâ, U. (2003). Reduced expression of the inducible nitric oxide synthase after infection with Toxoplasma gondii facilitates parasite replication in activated murine macrophages. International Journal for Parasitology 33: 833-844. https://doi.org/10.1016/ s0020-7519(03)00092-4

Mahmoudvand, H., Sheibani, V., Shojaee, S., Mirbadie, S.R., Keshavarz, H., Esmaeelpour, K., Keyhani, A.R. \& Ziaali, N. (2016). Toxoplasma gondii infection potentiates cognitive impairments of Alzheimer's disease in the BALB/c mice. Journal of Parasitology 102: 629-635. https://doi.org/10.1645/ 16-28

Mahmoudvand, H., Ziaali, N., Aghaei, I., Sheibani, V., Shojaee, S., Keshavarz, H. \& Shabani, M. (2015). The possible association between Toxoplasma gondii infection and risk of anxiety and cognitive disorders in BALB/C mice. Pathogens and Global Health 109: 369-376. https://doi.org/ 10.1080/20477724.2015.1117742

Meira, C.S., Pereira-Chioccola, V.L., Vidal, J.E., de Mattos, C.C., Motoie, G., Costa-Silva, T.A., Gava, R., Frederico, F.B. \& de Mattos, L.C. (2014). Cerebral and ocular toxoplasmosis related with IFN- $\gamma$, TNF- $\alpha$, and IL-10 levels. Frontiers in Microbiology 5: 492. https://doi.org/10.3389/fmicb.2014. 00492

Moon, S., Lee, S., Kim, H., Freitas-Junior, L.H., Kang, M., Ayong, L. \& Hansen, M.A. (2013). An image analysis algorithm for malaria parasite stage classification and viability quantification. PloS One 8: e61812. https://doi.org/10.1371/ journal.pone.0061812
Mortensen, P.B., Nørgaard-Pedersen, B., Waltoft, B.L., Sørensen, T.L., Hougaard, D. \& Yolken, R.H. (2007). Early infections of Toxoplasma gondii and the later development of schizophrenia. Schizophrenia Bulletin 33: 741-744. https://doi.org/10.1093/schbul/sbm009

Nishikawa, Y., Kawase, O., Vielemeyer, O., Suzuki, H., Joiner, K.A., Xuan, X. \& Nagasawa, H. (2007). Toxoplasma gondii infection induces apoptosis in noninfected macrophages: role of nitric oxide and other soluble factors. Parasite Immunology 29: 375-385. https://doi.org/10.1111/j.13653024.2007.00956.x

Okusaga, O., Langenberg, P., Sleemi, A., Vaswani, D., Giegling, I., Hartmann, A.M., Konte, B., Friedl, M., Groer, M.W. \& Yolken, R.H. (2011). Toxoplasma gondii antibody titers and history of suicide attempts in patients with schizophrenia. Schizophronia Research 133: 150-155. https://doi.org/10.1016/ j.schres.2011.08.006

Olmos, G. \& Lladó, J. (2014). Tumor necrosis factor alpha: a link between neuroinflammation and excitotoxicity. Mediators of Inflammation 2014: 861231. https://doi.org/ $10.1155 / 2014 / 861231$

Raisova, M., Hossini, A.M., Eberle, J., Riebeling, C., Orfanos, C.E., Geilen, C.C., Wieder, T., Sturm, I. \& Daniel, P.T. (2001). The $\mathrm{Bax} / \mathrm{Bcl}-2$ ratio determines the susceptibility of human melanoma cells to CD95/Fas-mediated apoptosis. Journal of Investigative Dermatology 117: 333-340. https:// doi.org/10.1046/j.0022-202x.2001.01409.x

Russ, J.C. \& Russ, J.C. (2017). Introduction to image processing and analysis. CRC press (editor) 1 edition. USA: Boca Raton, pp. 19. https://doi.org/10.1201/9781315221939

Scharton-Kersten, T.M., Yap, G., Magram, J. \& Sher, A. (1997). Inducible nitric oxide is essential for host control of persistent but not acute infection with the intracellular pathogen Toxoplasma gondii. Journal of Experimental Medicine 185: 1261-1273. https://doi.org/10.1084/jem.185.7.1261

Schlüter, D., Deckert-Schlüter, M., Lorenz, E., Meyer, T., Röllinghoff, M. \& Bogdan, C. (1999). Inhibition of inducible nitric oxide synthase exacerbates chronic cerebral toxoplasmosis in Toxoplasma gondii-susceptible C57BL/ 6 mice but does not reactivate the latent disease in $T$. gondii-resistant BALB/c mice. The Journal of Immunology 162: 3512-3518.

Schlüter, D., Kwok, L.Y., Lütjen, S., Soltek, S., Hoffmann, S., Körner, H. \& Deckert, M. (2003). Both lymphotoxin- $\alpha$ and TNF are crucial for control of Toxoplasma gondii in the central nervous system. Journal of Immunology 170: 6172-6182. https://doi.org/10.4049/jimmunol.170.12.6172

Smith, K.J., Kapoor, R. \& Felts, P.A. (1999). Demyelination: the role of reactive oxygen and nitrogen species. Brain Pathology 9: 69-92. https://doi.org/10.1111/j.17503639.1999.tb00212.x

Szabo, E.K. \& Finney, C.A. (2017). Toxoplasma gondii: one organism, multiple models. Trends in Parasitology 33:113127. https://doi.org/10.1016/j.pt.2016.11.007

Takahashi, J., Fukuda, T., Tanaka, J., Minamitani, M., Onouchi, K. \& Makioka, A. (2001). Bax-induced apoptosis not demonstrated in the congenital toxoplasmosis in mice. Brain and Development 23: 50-53. https://doi.org/10.1016/ S0387-7604(01)00179-6

Tobin, C.M. \& Knoll, L.J. (2012). A patatin-like protein protects Toxoplasma gondii from degradation in a nitric oxidedependent manner. Infection and Immunity 80: 55-61. https://doi.org/10.1128/IAI.05543-11 
Torrey, E.F., Bartko, J.J. \& Yolken, R.H. (2012). Toxoplasma gondii and other risk factors for schizophrenia: an update. Schizophrenia Bulletin 38: 642-647. https://doi.org/10.1093/ schbul/sbs043

Williams, G.T. (1994). Programmed cell death: a fundamental protective response to pathogens. Trends in Microbiology 2: 463-464. https://doi.org/10.1016/0966-842x(94)90648-3

Wu, L., Wang, X., Li, Y., Liu, Y., Su, D., Fu, T., Guo, F., Gu, L., Jiang, X. \& Chen, S. (2016). Toxoplasma gondii ROP18: potential to manipulate host cell mitochondrial apoptosis. Parasitology Research 115: 2415-2422. https://doi.org/10.1007/ s00436-016-4993-6
Yao, Y., Liu, M., Ren, C., Shen, J. \& Ji, Y. (2017). Exogenous tumor necrosis factor-alpha could induce egress of Toxoplasma gondii from human foreskin fibroblast cells. Parasite 24: 45. https://doi.org/10.1051/parasite/2017051

Yolken, R.H., Dickerson, F.B. \& Fuller Torrey, E. (2009). Toxoplasma and schizophrenia. Parasite Immunology 31: 706-715. https://doi.org/10.1111/j.1365-3024.2009.01131.x

Zhang, X.C., Cai, N.G., Sun, L., Luo, Q. \& An, F. (2007). Apoptosis of human leukemia K562 cell in vitro induced by Toxoplasma gondii. Zhongguo ji sheng chong xue yu ji sheng chong bing za zhi $=$ Chinese Journal of Parasitology \& Parasitic Diseases 25: 185-188. 